\title{
PEMANFAATAN POTENSI ALIRAN AIR SUNGAI SEBAGAI PEMBANGKIT LISTRIK MIKRO HIDRO
}

\author{
Subianto $^{1}$ / Raden Ahmad Yani ${ }^{2}$ / Amdaniel Hermanto Marbun ${ }^{3}$ \\ subiantodaeny07@gmail.com ${ }^{1} /$ ray@gmail.com ${ }^{2}$ \\ Dosen Tetap Prodi Teknik Elektro Fakultas Teknik Universitas Palembang ${ }^{1 \& 2}$ \\ Alumni Prodi Teknik Elektro Universitas Palembang ${ }^{3}$
}

\begin{abstract}
ABSTRAK
Pembangkit listrik adalah suatu alat yang dapat membangkitkan dan memproduksi energi listrik dengan cara mengubah suatu energi tertentu menjadi energi listrik. Baik dari aliran air, gas, uap, dan lain lain. Penelitian yang dilakukan bertujuan mendesain kincir dan mendapatkan nilai potensi daya energi listrik yang mampu dihasilkan dari aliran air sungai bungin tambun Kabupaten Kaur. Dengan mengumpulkan data dan mempelajari buku-buku kajian (studi pustaka) yang berkenaan dengan Pembangkit Listrik Tenaga Aliran Sungai, serta mempelajari jurnal-jurnal, berkas-berkas dan arsiparsip yang menunjang mengenai komponen pembangkit.Mengambil data secara langsung ke tempat objek penelitian. Setelah itu, data yang diperoleh, berupa teori dan rumusan itu menjadi referensi untuk penelitian ini. Aliran air yang ada pada aliran sungai Bungin Tambun dapat dimanfaatkan menjadi Pembangkit listrik dengan memperhatikan lokasi dari potensi air, debit yang tersedia, desain kincir air, dan pemilihan jenis generator yang sesuai berdasarkan dari data hasil perhitungan. Pada sungai ini digunakan jenis kincir tipe undershot. Ukuran kincir maksimal yang dapat di bangun pada sungai bungin tambun sebesar 3 meter, lebar 0,7 meter dan kedalaman sudu kincir yang terkena air 0,5 meter.Pada sungai bungin tambun yang terletak dikecamatan padang guci mempunyai debit area kincir sebesar $12,54 \mathrm{~m}^{3} / \mathrm{s}$ dan debit jangkauan kincir sebesar $8,73 \mathrm{~m}^{3} / \mathrm{s}$. Potensi daya yang dapat dihasilkan pada sungai bungin tambun dengan ukuran kincir 2 meter dan efisiensi $100 \%$ bisa mencapai 6930 watt atau $6,9 \mathrm{~kW}$. Sungai bungin tambun padang guci mempunyai potensi energi yang dapat dibangkitkan sebesar 2.079 watt atau $2 \mathrm{~kW}$. Studi awal pada sungai ini menggunakan generator magnet permanen $2 \mathrm{~kW}$ dengan RPM 150.
\end{abstract}

Kata Kunci : Pembangkit Listrik, Bungin Tambun, Aliran Sungai, Watt

\section{PENDAHULUAN}

\subsection{Latar Belakang}

Energi listrik memegang peranan yang sangat penting dalam perkembangan ekonomi dan pembangunan suatu bangsa. Kebutuhan akan energi listrik pada umumnya akan semakin meningkat seiring dengan membaiknya perekonomian, pertambahan jumlah penduduk dan kemajuan teknologi informasi. Sedangkan pertumbuhan ini tidak sejalan dengan ketersediaan bahan bakar yang ada untuk membangkitkan energi listrik.Hal ini dikarenakan sebagian besar suplai energi listrik berasal dari pembangkit lsitrik berbahan bakar minyak dan batubara. Ketergantungan akan bahan bakar fosil ini tentu saja mempunyai banyak dampak buruk. Inilah yang menimbulkan kesadaran untuk mengembangkan pembangkit listrik yang bersumber energi terbarukan.Selain tingginya harga bahan bakar minyak, upaya ini dipengaruhi juga oleh menipisnya cadangan minyak dalam negeri. (Suyitno, 2011)

Sebenarnya terdapat energi alternatif yang murah dan ramah lingkungan, yaitu air.Air merupakan sumber energi yang murah dan relatif mudah didapat.Indonesia memiliki potensi sumber energi terbarukan dalam jumlah besar, salah satunya tenaga air yang bisa digunakan untuk membangkitkan energi listrik.Pembangkit Listrik Tenaga Aliran Air Sungai merupakan pembangkit energi alternatif yang menggunakan aliran air sebagai energi terbarukan.Pembangkit Listrik Tenaga Aliran Air Sungai ini menggunakan peralatan yang sederhana serta kecilnya area tanah yang 
diperlukan guna instalasi dan pengoperasian. Hal tersebut merupakan salah satu keunggulan Pembangkit Listrik Tenaga Aliran Air Sungai, yaitu tidak menimbulkan kerusakan lingkungan.

\subsection{Tujuan Penelitian}

Sesuai dengan penelitian yang dilakukan maka tujuan dari penelitian ini adalah mendesain kincir dan mendapatkan nilai potensi daya energi listrik yang mampu dihasilkan dari aliran air sungai bungin tambun Kabupaten Kaur.

\subsection{Manfaat Penelitian}

Beberapa manfaat yang dapat diambil penelitian ini diantaranya yaitu :

1. Dapat membantu mengurangi penggunaan beban dari PLN

2. Dapat menghemat perekonomian penduduk sekitar

3. Dapat menghemat ketersediaan bahan bakar minyak dan fosil.

\subsection{Ruang Lingkup Penelitian}

Penelitian dilakukan dengan menganalisa kemampuan aliran air Sungai Bungin Tambun sebagai pembangkit listrik dengan menghitung energi yang dihasilkan. Studi awal dibatasi pada aliran air sungai bungin tambun Kabupaten Kaur.

\section{TINJAUAN PUSTAKA}

\subsection{Potensi Sumber Daya Air}

Air merupakan salah satu sumber daya alam yang memiliki fungsi sangat penting bagi hidup dan kehidupan seluruh makhluk hidup, termasuk manusia.Dari air bermula kehidupan dan karena air peradaban tumbuh berkembang. ${ }^{(\text {Samekto, } 2016)}$

Hukum Thermodinamika Pertama biasa disebut hukum konversi energy. Hukum tersebut menyatakan bahwa energi tidak dapat diciptakan ataupun dihancurkan, tetapi energi dapat berpindah dari satu bentuk ke bentuk lain. Misalnya Energi Air dapat diubah menjadi Energi Listrik. ${ }^{\text {(Tedjasaputra, }}$ 2012)

Potensi air ini dapat dimanfaatkan untuk pembangkit tenaga listrik dengan kapasitas yang cukup besar, banyaknya sungai dan danau air tawar yang berada di indonesia merupakan modal awal untuk pengembangan energi air ini. Namun eksploitasi terhadap sumber energi ini juga harus memperlihatkan ekosistem lingkungan yang sudah ada.

Sungai Bungin Tambun merupakan salah satu dari beberapa sungai yang melintas di Kabupaten Kaur8.00 km dan daerah aliran $8.692 \mathrm{~km}^{2}$.Sungai Bungin Tambun merupakan sungai yang mengalir sepanjang tahunnya, pada musim hujan Sungai Bungin Tambun mempunyai debit air yang cukup besar sedangkan pada musim kemarau Sungai Bungin Tambun mempunyai debit air yang kecil. Bagian hulu sungai merupakan daerah perbukitan yang airnya dimanfaatkan untuk memenuhi kebutuhan air baku oleh masyarakat. ${ }^{\text {(Baskoro, 2009) }}$

\subsection{Debit Aliran Air}

Debit aliran adalah laju aliran air (dalam bentuk volume air) yang melewati suatu penampang melintang sungai per satuan waktu. Dalam sistem satuan SI besarnya debit dinyatakan dalam satuan meter kubik per detik $\left(\mathrm{m}^{3} / \mathrm{dt}\right)$. Dalam laporan-laporan teknis, debit aliran air biasanya ditunjukkan dalam bentuk hidrograf aliran. Hidrograf aliran adalah suatu perilaku debit sebagai respons adanya perubahan karakteristik biogeofisik yang berlangsung dalam suatu DAS (oleh adanya kegiatan pengelolaan DAS) dan/ atau adanya perubahan (fluktuasi musiman atau tahunan) iklim lokal. ${ }^{(\text {Asdak, 2002) }}$ Teknik pengukuran debit aliran langsung di lapangan pada dasarnya dapat dilakukan melalui empat kategori : (Gordon, 1992)

1) Pengukuran volume air sungai

2) Pengukuran debit dengan cara mengukur kecepatan aliran dan menentukan luas penampang melintang sungai

3) Pengukuran debit dengan menggunakan bahan kimia yang dialirkan dalam aliran sungai (substance tracing method). 
4) Pengukuran debit dengan membuat bangunan pengukur debit seperti weir (aliran air lambat) atau flume (aliran air cepat)

\subsection{Pembangkit Listrik Tenaga Air}

Pembangkit listrik tenaga air adalah pembangkit listrik yang menggunakan aliran air sebagai sumber energinya. Aliran air digunakan untuk memutar turbin ataupun kincir yang menggerakkan generator untk menghasilkan energi listrik.

Untuk bisa menghasilkan energi listrik dari air, harus melalui beberapa tahapan perubahan energi yaitu :

1. Energi Potensial

2. Energi Kinetis

3. Energi Kinetis

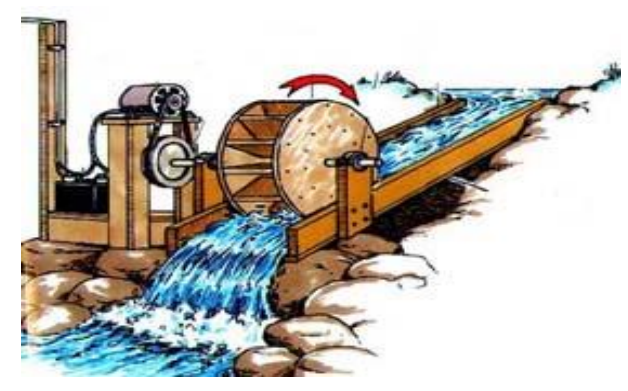

Gambar 2.1. PLTA dengan Kincir (Pembangkit Listrik Memanfaatkan Tenaga Air, 2020)

\section{Jenis - Jenis PLTA}

Berdasarkan ukuran dan daya yang dibangkitkan PLTA dibagi menjadi beberapa jenis yaitu :

1. Large Hydro merupakan pembangkit dengan daya yang dihasilkan lebih dari $100 \mathrm{MW}$. Pembangkit Large Hydro memerlukan area yang luas dan ketersediaan air yang banyak.

2. Medium Hydro memiliki konsep yang sama dengan Large Hydro, Namun daya yang dihasilkan lebih kecil berkisar 15 - $100 \mathrm{MW}$.

3. Small Hydro merupakan pembangkit dengan daya yang dihasilkan berkisar 1-15 MW.

4. Mini Hydro merupakan pembangkit dengan daya diatas 100 Kilowatt. Namun kurang dari $1 \mathrm{MW}$.

5. Micro Hydro merupakan pembangkit dengan daya yang dihasilkan 5 - 100 Kilowatt. Biasa digunakan untuk komunitas atau daerah-daerah dan industri kecil.

6. Pico Hydro merupakan pembangkit dengan daya kurang dari 5 Kilowatt.

Komponen - Komponen PLTA

- Kincir Air (Water Wheel)

$\checkmark$ Undershot Waterwheel (Vertical Wheel)

$\checkmark$ Overshot Waterwheel (Vertical Wheel)

$\checkmark$ Breastshot Waterwheel (Vertical Wheel)

- Kincir Air Tub

- Generator

$\checkmark$ Generator Magnet Permanen

\section{METODOLOGI PENELITIAN}

\subsection{Langkah - Langkah Analisa Data}

Langkah-langkah yang diambil sebagai bahan analisa adalah sebagai berikut:

1. Pengambilan Data

Pengambilan data langsung ke tempat objek penelitian. Seperti data, debit air, luas penampang, dan tinggi jatuh air.

2. Perhitungan Data 
Data yang telah diperoleh kemudian dihitung dengan menggunakan rumus-rumus yang berkenaan dengan penentuan kapasitas besar pembangkit.

3. Pembahasan Hasil dan Analisa Data

Dari hasil perhitungan data yang menggunakan rumus-rumus tersebut akan diperoleh suatu informasi yang dapat dibahas dan dapat dianalisa meliputi : besar kapasitas daya yang dihasilkan dan desain yang dipakai.

\subsection{Diagram Alur Penelitian}

Adapun diagram alur penelitian yang diperoleh berdasarkan langkah-langkah penelitian diatas, yaitu :

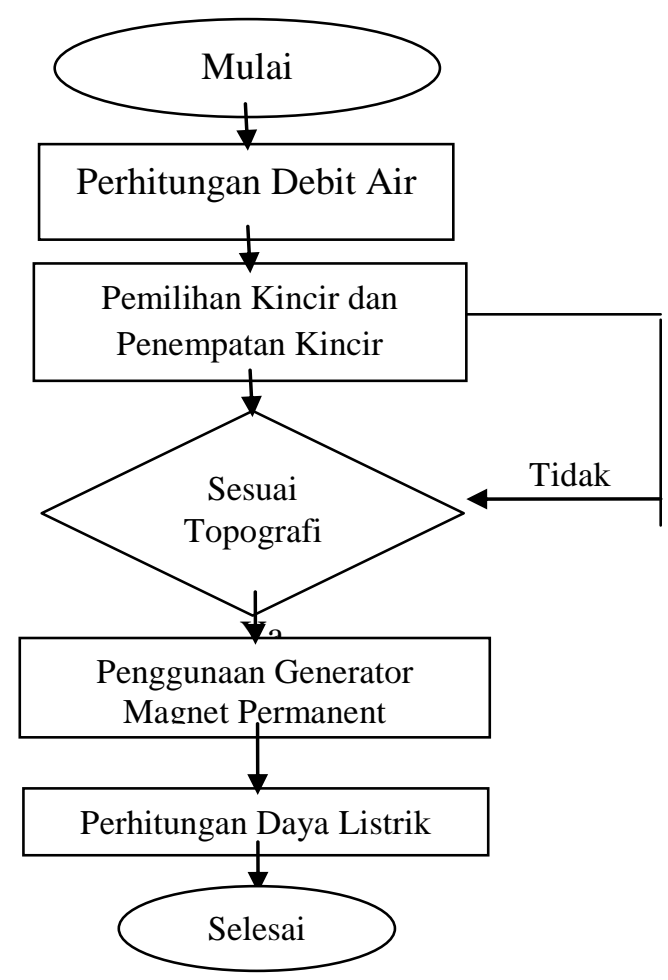

Gambar 3.1. Diagram Alur Penelitian

\section{ANALISA DAN PEMBAHASAN}

\subsection{Pemilihan Jenis Kincir}

Sungai Bungin Tambun yang berada di kecamatan Padang Guci Kabupaten Kaur mempunyai tipe sungai yang berbatu dengan aliran air yang cukup deras dan tidak terlalu dalam yang dapat dimanfaatkan sebagai sumber pembangkit listrik. Berdasarkan topografi sungai yang tidak memiliki head atau jatuh tinggi dikarenakan hanya memanfaatkan kecepatan aliran air sebagai sumbernya maka parameter-parameter kincir yang dipilih, sebagai berikut :

- Tipe

: Kincir Undershot

- Bahan

: Kayu

- Ukuran

: 2 meter

- Lebar

: 0,7 meter

- Kedalaman Sudu Terkena Air : 0,5 meter

- RPM : 12

Digunakannya bahan kayu pada kincir dikarenakan kayu mudah ditemui atau banyak dijumpai,kayu tidaklah berat jika dibandingkan dengan menggunakan plat besi dan dengan bahan kayu pula perawatan pada kincir lebih mudah dan hemat pembiayaan. Pada dasarnya lokasi pada 
penempatan kincir mempunyai potensi maksimum \pm 3 meter namun agar lebih efisien maka kincir yang akan digunakan berukuran 2 meter dan dikarenakan lokasi kincir yang berbentukseperti aliran siring atau parit maka lebar dari kincir di asumsikan 0,7 meter dengan kedalaman sudu yang terkena air 0,5 meter. Pada kincir ini di asumsikan memiliki 16 buah sudu, dimana sudu merupakan salah satu hal penting pada kincir yang berfungsi sebagai penggerak kincir yang memanfaatkan kecepatan aliran air. Semakin banyak sudu maka semakin cepat pula kincir berputar. Berdasarkan data di atas maka dapat kita cari RPM kincir, yaitu :

Diketahui :

$$
\omega=\frac{v}{r}=\frac{1,26}{1}=1,26 \mathrm{rad} / \mathrm{s}
$$

1 putaran $=2 \pi \mathrm{rad}$

1 radian $=1 / 2 \pi$ putaran

Maka untuk $\omega=1,26$ :

$$
\begin{gathered}
\omega=\frac{v}{r} \\
1,26 \mathrm{rad}=\frac{1,26}{2 \pi}=0,2 \text { putaran } \\
\text { Jadi : } \omega_{\text {kincir }}=\frac{0,2 \text { putaran }}{\text { detik }}=\frac{0,26}{1 / 60}=0,2 \times 60 \text { putaran } / \text { menit }=12 \mathrm{rpm}
\end{gathered}
$$

Maka RPM yang dihasilkan dengan ukuran diatas didapatlah rpm kincir sebesar 12 RPM.

\begin{tabular}{|c|c|c|c|}
\hline $\begin{array}{l}\text { Percobaan } \\
\text { ke- }\end{array}$ & Jarak (s) (m) & $\begin{array}{c}\text { Waktu (t) } \\
(\mathrm{s})\end{array}$ & $\begin{array}{c}\text { Kecepatan }(\mathbf{v}) \\
(\mathbf{m} / \mathbf{s})\end{array}$ \\
\hline 1. & 2 & 1,67 & 1,20 \\
\hline 2. & 2 & 1,59 & 1,25 \\
\hline 3. & 2 & 1,54 & 1,30 \\
\hline 4. & 2 & 1,72 & 1,16 \\
\hline 5. & 2 & 1,57 & 1,27 \\
\hline 6. & 2 & 1,51 & 1,32 \\
\hline 7. & 2 & 1,48 & 1,35 \\
\hline 8. & 2 & 1,63 & 1,22 \\
\hline 9. & 2 & 1,48 & 1,35 \\
\hline 10. & 2 & 1,66 & 1,20 \\
\hline$\sum n=10$ & & & $\sum v=12,26$ \\
\hline
\end{tabular}

Berikut ini adalah data hasil pengukurannya :

$$
\begin{array}{ll}
\text { Lebar sungai } & : 1 \mathrm{~m} \\
\text { Kedalaman sungai } & : 0,7 \mathrm{~m}
\end{array}
$$

Tabel 4.1. Data Hasil Pengukuran Kecepatan Aliran Air

Dari data diatas dapat kita hitung kecepatan rata-rata aliran air, yaitu :

\section{Luas Area Kincir}

$$
v_{\text {rata-rata }}=\frac{\sum v}{\sum n}=\frac{12,26}{10}=1,262 \mathrm{~m} / \mathrm{s}
$$

Dengan data diatas maka luas area kincir dapat dihitung yaitu:

$$
\begin{gathered}
A=2\{(p \times l)+(p \times t)+(l \times t)\} \times v_{\text {rata-rata }} \\
A=2\{(3 \times 0,7)+(3 \times 0,5)+(0,7 \times 0,5)\} \times 1,262 \\
A=2\{(2,1+1,5+0,35)\} \times 1,262=9,954 \mathrm{~m}^{2}
\end{gathered}
$$

Jadi luas area kincir yang didapat pada sungai Bungin Tambun Padang Guci sebesar 9,954 $\mathrm{m}^{2}$. 


\section{Luas Jangkauan Kincir}

Dengan data diatas maka luas jangkauan kincir dapat dihitung, yaitu :

$$
\begin{gathered}
A=2\{(p x l)+(p x t)+(l \times t)\} \times v_{\text {rata-rata }} \\
A=2\{(2 \times 0,7)+(2 \times 0,5)+(0,7 \times 0,5)\} \times 1,262 \\
A=2\{(1,4+1+0,35)\} \times 1,262=6,93 \mathrm{~m}^{2}
\end{gathered}
$$

Jadi luas jangkauan kincir yang didapat pada sungai Bungin Tambun Padang Guci sebesar $6,93 \mathrm{~m}^{2}$.

\section{Debit Area Kincir}

Dengan data diatas dapat dihitung besarnya debit $(\mathrm{Q})$ area kincir, yaitu :

$$
\begin{gathered}
Q=v \times A \\
Q=1,262 \times 9,954=12,54 \mathrm{~m}^{3} / \mathrm{s}
\end{gathered}
$$

Jadi debit area kincir yang didapat pada Sungai Bungin Tambun Padang Guci sebesar 12,54 $\mathrm{m}^{3} / \mathrm{s}$

\section{Debit Jangkauan Kincir}

Dengan data diatas maka dapat di hitung besar debit jangkauan kincir, yaitu :

$$
\begin{aligned}
\operatorname{Debit}(\mathrm{Q}) & =\mathrm{v} \cdot \mathrm{A} \\
& =1,26 \times 6,93 \\
& =8,73 \mathrm{~m}^{3} / \mathrm{s}
\end{aligned}
$$

Jadi debit jangkauan kincir yang didapat pada Sungai Bungin Tambun Padang Guci sebesar $8,73 \mathrm{~m}^{3} / \mathrm{s}$

\subsection{Perhitungan Daya Listrik yang Dapat Dibangkitkan}

Total daya listrik yang dapat dibangkitkan dengan nilai efisiensi 1 atau nilai efisiensi $100 \%$ adalah sebesar :

$$
\begin{aligned}
\mathrm{P} & =1 / 2 \times \eta \times \rho \times \mathrm{A}^{3} \mathrm{v}^{3} \\
& =1 / 2 \times \eta \times 1000 \times 6,93 \times 1,26^{3} \\
& =1 / 2 \times \eta \times 1000 \times 6,93 \times 2 \\
& =1 / 2 \times \eta \times 13860 \\
& =6.930 \mathrm{Watt}
\end{aligned}
$$

Jadi dengan nilai efisiensi 100\% daya yang dapat dibangkitkan oleh kincir sebesar 6.930 Watt atau 6,9 $\mathrm{kW}$.

Total daya listrik yang dapat dibangkitkan dengan nilai efisiensi 0,3 atau nilai efisiensi $30 \%$ adalah sebesar :

$$
\begin{aligned}
\mathrm{P} & =1 / 2 \times \eta \times \rho \times \mathrm{A}^{3} \mathrm{v}^{3} \\
& =1 / 2 \times 0,3 \times 1000 \times 6,93 \times 1,26^{3} \\
& =1 / 2 \times 0,3 \times 1000 \times 6,93 \times 2 \\
& =1 / 2 \times 0,3 \times 13860 \\
& =2.079 \text { Watt }
\end{aligned}
$$

Jadi dengan nilai efisiensi 30\% daya yang dapat dibangkitkan oleh kincir sebesar 2.079 Watt atau 2 $\mathrm{kW}$.

\subsection{Kebutuhan Beban}

Daya yang dihasilkan oleh kincir dimanfaatkan untuk kebutuhan listrik sehari-hari di kawasan dekat sungai yang berlokasi di Kecamatan Padang Guci yang terdiri dari :

- 17 unit bangunan Pos Ronda, 1 unit Pos Ronda terdiri dari 1 buah lampu yang masing- masing lampu dengan daya 23 Watt.

- 5 unit bangunan wc umum, 1 unit wc terdiri dari 2 buah lampu dengan masing-masing daya 23 Watt.

- 1 unit bangunan Balai Desa terdiri dari 1 buah televisi 21 inch dengan daya 100 Watt, 1 buah kipas angin dengan daya 45 Watt, 4 buah lampu masing-masing 23 Watt dan 1 buah kulkas dengan daya 150 Watt.

- 10 unit lampu penerangan, 1 unit lampu dengan daya 23 Watt.

Total daya yang dibutuhkan untuk seluruhnya :

- Pos Ronda

17 unit $\mathrm{x} 23$ watt

$=391 \mathrm{Watt}$ 
- Wc Umum

- Balai Desa

- Lampu Penerangan

Total Beban

$$
\begin{array}{ll}
5 \text { unit } \times 46 \text { watt } & =230 \text { Watt } \\
1 \text { unit } \times 387 \text { watt } & =387 \text { Watt } \\
10 \text { unit x 23 watt } & =\underline{230 \text { Watt }} \\
& =1238 \text { Watt }
\end{array}
$$

Jadi total beban yang dibutuhkan di kecamatan padang guci sebesar 1.238 Watt atau 1,2 kW.

\subsection{Pemilihan Jenis Generator}

Pemilihan jenis generator didasarkan dari daya yang telah dibangkitkan dan rpm pada kincir, pada sungai bungin tambun daya yang telah dibangkitkan sebesar $2 \mathrm{~kW}$ dan putaran/menit pada kincir sebesar $12 \mathrm{rpm}$. Pada hal ini penulis memilih jenis generator dengan magnet permanent dikarenakan jenis magnet ini dapat bekerja di putaran rendah tanpa menggunakan gearbox, biaya perawatan yang rendah dan tidak memerlukan tegangan eksitasi dari luar.

Maka parameter-parameter generator yang dipilih sebagai berikut :

Jenis

: Generator Magnet Permanent

Kapasitas $\quad: 2 \mathrm{~kW}-2,2 \mathrm{~kW}$

Kecepatan Putar $\quad: 150 \mathrm{rpm}$

Diameter Rotor $\quad: 3 \mathrm{~cm}$

Pada hal ini dikarenakan rpm generator tidak sama dengan Rpm kincir maka akan dipasang pulley dan belt sebagai penghubung antara kincir dan generator. Pulley dapat dihitung dengan asumsi pulley pada generator $3 \mathrm{~cm}$ sebagai berikut :

$$
\begin{aligned}
\omega_{\mathrm{pk}} \cdot \mathrm{r}_{\mathrm{pk}} & =\omega_{\mathrm{pg}} \cdot \mathrm{r}_{\mathrm{pg}} \\
12 \cdot \mathrm{r}_{\mathrm{pk}} & =150 \cdot 3 \mathrm{~cm} \\
\mathrm{r}_{\mathrm{pk}} & =\frac{150.3}{12} \\
= & 37.5 \mathrm{~cm}
\end{aligned}
$$

Berdasarkan data diatas maka di dapat spesifikasi masing-masing pulley dan rasio perbandingan antara generator dan kincir adalah sebagai berikut :

$\begin{array}{ll}\text { Pulley Generator } & : 6 \mathrm{~cm} \\ \text { Pulley Kincir } & : 75 \mathrm{~cm} \\ \text { Rasio Perbandingan } & : 1: 40 \\ \text { Spesifikasi : } & \end{array}$

- Kincir 2 meter

- Lebar kincir 0,7 meter

- Sudu terkena air 0,5 meter

- Pulley Kincir $75 \mathrm{~cm}$

- Pulley Generator $6 \mathrm{~cm}$

- Belt Karet

- Rasio Perbandingan $1: 40$

\section{PENUTUP}

Berdasarkan dari perhitungan dan analisa maka didapatkan beberapa kesimpulan diantaranya :

1. Aliran air sungai mempunyai potensi yang dapat dimanfaatkan sebagai pembangkit listrik.

2. Pada sungai ini digunakan jenis kincir tipe undershot.

3. Ukuran kincir maksimal yang dapat di bangun pada sungai bungin tambun sebesar 3 meter, lebar 0,7 meter dan kedalaman sudu kincir yang terkena air 0,5 meter.

4. Pada sungai bungin tambun yang terletak dikecamatan padang guci mempunyai debit area kincir sebesar $12,54 \mathrm{~m}^{3} / \mathrm{s}$ dan debit jangkauan kincir sebesar $8,73 \mathrm{~m}^{3} / \mathrm{s}$.

5. Potensi daya yang dapat dihasilkan pada sungai bungin tambun dengan ukuran kincir 2 meter dan efisiensi $100 \%$ bisa mencapai 6930 watt atau $6,9 \mathrm{~kW}$.

6. Sungai bungin tambun padang guci mempunyai potensi energi yang dapat dibangkitkan sebesar 2.079 watt atau $2 \mathrm{~kW}$.

7. Studi awal pada sungai ini menggunakan generator magnet permanen $2 \mathrm{~kW}$ dengan RPM 150. 


\section{DAFTAR PUSTAKA}

Pembangkit listrik memanfaatkan tenaga air. (2020, 05 30). Diambil kembali dari Legenda: http://sanfordlegenda.blogspot.com/2013/09/Pembangkit-listrik-memanfaatkan-tenagaair.html

Analysis, P. S. (2011, July 20). Turbine Generator. Dipetik 5 31, 2020, dari http://turbinegenerators.blogspot.com/2011/07/undershot-waterwheelwater-turbine.html

Asdak, C. (2002). Hidrologi dan Pengelolaan Daerah Aliran Sungai. Gadjah Mada University Press .

Qtussama. (2016). Generator Listrik. Diambil kembali dari Qtussama: https://qtussama.wordpress.com/materi-ajar-x-tkr/generator-listrik/

Samekto, C. (2016). Potensi Sumber Daya Air di Indonesia. Seminar Nasional Aplikasi Teknologi Penyediaan Air Bersih untuk Kabupaten/Kota di Indonesia, 1.

Stanford Magnet. (2017). Typical Structure and Working Principle of Permanent Magnet Alternator. Diambil kembali dari Stanford Magnet: http://www.usneodymiummagnets.com/typicalstructure-and-working-principle-of-permanent-magnet-alternator.html

Sule, L. (2014). Kinerja Roda Air Sudu Lengkung Arus Bawah untuk Pembangkit Listrik. Prosiding Seminar Ilmiah Nasional Sains dan Teknologi ke 4 Tahun 2018, 451.

Suyitno, D. (2011). Pembangkit Energi Listrik. Rineka Cipta. 